\title{
EPIDEMIOLOGY OF FEMORAL SHAFT FRACTURES IN POLAND
}

\section{EPIDEMIOLOGIA ZŁAMAŃ TRZONÓW KOŚCI UDOWEJ W POLSCE}

\author{
${ }^{1}$ Medical University of Warsaw, Department of Pediatric Emergency Medicine. \\ ${ }^{2}$ Medical Centre of Postgraduate Education, Department of Orthopaedics, \\ Pediatric Orthopaedics and Traumatology \\ ${ }^{1}$ Warszawski Uniwersytet Medyczny, Wydział Nauki o Zdrowiu, Zakład Medycyny Ratunkowej Dzieci \\ ${ }^{2}$ Centrum Medycznego Kształcenia Podyplomowego, Klinika Ortopedii, Ortopedii i Traumatologii Dziecięcej
}

\section{ABSTRACT}

INTRODUCTION. Femoral shaft fractures are undoubtedly a common issue in orthopedic practice, which frequently requires surgical treatment. The clinical significance of such fractures is high, but the statistics of their occurrence was not covered in any comprehensive study in Polish medical literature.

THE AIM OF THE STUDY. The study aimed to assess the incidence of femoral shaft fractures in the Polish population with particular reference to the mechanism of such events in pediatric patients.

MATERIAL AND METHODS. The assessment of the total incidence and the incidence in individual age groups was performed basing on data concerning 2015-2018 obtained from the National Health Fund. Data regarding the mechanism of the event were obtained at the Pediatric Teaching Clinical Hospital, University Clinical Center of the Medical University of Warsaw.

RESULTS. We assessed the total incidence at the level of 10.5 cases per 100000 inhabitants yearly in Poland. A significant difference was noted in the incidence in individual age groups, particularly in the elderly. The incidence of femoral shaft fractures in patients older than 70 was twofold higher than in the general population. The paper also tackles the issue of mortality in patients with femoral shaft fractures, which reaches $16 \%$ annually. High-energy trauma was responsible for the majority of femoral shaft fractures in children with the dominant activity being trampoline jumping. At the same time, the incidence was comparable between boys and girls.

CONCLUSIONS. The obtained results were discussed against statistics concerning other countries with the outcomes being rather similar. No significant differences were observed as regards the Polish population versus populations of other countries.

Key words: Femur, femoral fracture, children, epidemiology

\section{STRESZCZENIE}

WSTĘP. Złamanie trzonu kości udowej jest niewątpliwie zdarzeniem częstym w praktyce ortopedycznej i wielokrotnie wymagającym leczenia poprzez zabieg operacyjny. Znaczenie kliniczne tego typu złamania jest poważne, jednakże w polskiej literaturze medycznej nie zostało jeszcze przedstawione kompleksowe opracowanie dotyczące statystyki występowania tych złamań.

CEL PRACY. Celem pracy była ocena zapadalności na złamanie trzonu kości udowej w populacji polskiej, wraz ze szczegółowym odniesieniem się do mechanizmu zdarzenia u pacjentów pediatrycznych.

MATERIAŁ I METODY. Ocena zapadalności ogólnej, jak i w poszczególnych grupach wiekowych była przeprowadzona na podstawie danych z lat 2015-2018 otrzymanych z Narodowego Funduszu Zdrowia. Dane dotyczące mechanizmu zdarzenia zostały uzyskane z Dziecięcego Szpitala Klinicznego Uniwersyteckiego Centrum Klinicznego WUM.

WYNIKI. W pracy oszacowano zapadalność ogólną na poziomie 10,5 przypadku na 100000 mieszkańców rocznie w Polsce. Zauważono istotną różnicę w częstości zdarzeń w poszczególnych grupach wiekowych,

C National Institute of Public Health - National Institute of Hygiene / Narodowy Instytut Zdrowia Publicznego - Państwowy Zakład Higieny 
w szczególności wśród osób starszych. Zapadalność na złamanie trzonu kości udowej wśród osób powyżej 70 roku życia jest ponad dwukrotnie wyższa niż w populacji ogólnej. W pracy odniesiono się również do kwestii śmiertelności pacjentów ze złamaniem trzonu kości udowej, która w perspektywie rocznej sięga 16\%. Najczęstszą przyczyną złamań trzonu kości udowej u dzieci były urazy wysokoenergetyczne, wśród których dominujące stały się skoki na trampolinie. Jednocześnie częstość złamań wśród chłopców i dziewcząt była bardzo podobna. PODSUMOWANIE. Uzyskane wyniki poddano dyskusji na tle statystyk z innych krajów, gdzie uzyskiwano dosyć zbieżne wyniki. Nie zaobserwowano w populacji polskiej istotnych różnic względem danych z innych krajów.

Słowa kluczowe: Kość udowa, złamanie kości udowej, dzieci, epidemiologia

\section{INTRODUCTION}

Femoral shaft fractures are rather common in traumatology practice. They constitute almost $1 \%$ of all fractures (1). Their sequelae may be serious for patients and are frequently associated with the necessity of surgical treatment. The epidemiological awareness of what such a fracture is, its incidence, the groups of increased risk and health consequences related to them, may offer the chance of a more effective organization of health care and the prophylaxis of events which lead to fractures. The review of Polish literature revealed no detailed analyses of data concerning femoral shaft fractures either in the adult or in the pediatric population. Therefore, the present authors performed analyses of data obtained from the National Health Fund and from Pediatric Teaching Clinical Hospital of the Medical University of Warsaw in order to determine the incidence of femoral shaft fractures in Poland.

\section{FEMORAL SHAFT FRACTURES}

The femur is the longest bone in the human locomotor system. Anatomically, the femur is a long bone. In adults its three segments are distinguished: the proximal epiphysis, diaphysis (shaft) and the distal epiphysis (2). In children the femur is divided into: the epiphysis, metaphysis and the diaphysis (shaft). Femoral shaft is one of the thickest and the most mechanically durable part of bones in the human body. Therefore, fractures within the femoral shaft area usually result from high-energy trauma, which requires substantial strength applied directly or indirectly to the femur. High-energy trauma commonly contributes to a major injury not only in the area of the femoral fracture, but it is also associated with multi-site or multiorgan trauma.

Anatomically, a femoral shaft fracture in adults is located in the area between $5 \mathrm{~cm}$ distally from the lesser trochanter and $5 \mathrm{~cm}$ proximally from the adductor tubercle (3). As regards the course of the fracture cleft we distinguish:

\section{WSTEP}

Złamania trzonów kości udowej są dość częstymi zdarzeniami w praktyce traumatologicznej, gdyż stanowią blisko $1 \%$ wszystkich złamań (1), a ich następstwa mogą być dla pacjentów poważne i wielokrotnie wiążą się z koniecznością leczenia operacyjnego. Świadomość epidemiologiczna, czym jest takie złamanie, jaka jest częstość występowania, jakie są grupy podwyższonego ryzyka i jakie może powodować następstwa zdrowotne, może dawać szanse nie tylko na lepszą organizację opieki zdrowotnej, ale i na profilaktykę zdrowotną zdarzeń prowadzących do złamań. W piśmiennictwie polskim autorzy nie odnaleźli pogłębionych analiz danych dotyczących złamań trzonu kości udowej tak w populacji dorosłej, jak i pediatrycznej, dlatego też dokonano analizy uzyskanych danych z Narodowego Funduszu Zdrowia oraz z Dziecięcego Szpitala Klinicznego Warszawskiego Uniwersytetu Medycznego, celem określenia częstości występowania złamań trzonów kości udowej w Polsce

\section{ZŁAMANIE TRZONU KOŚCI UDOWEJ}

Kość udowa jest najdłuższą kością w układzie ruchu człowieka. Anatomicznie kość udową zalicza się do grupy kości długich i u osób dorosłych wyróżnia się trzy części: koniec bliższy, trzon i koniec dalszy (2). U dzieci wyróżnia się w obrębie kości udowej: nasady, przynasady oraz trzon. Trzon kości udowej jest jedną z najgrubszych i najwytrzymalszych mechanicznie części kości w organizmie człowieka, dlatego złamanie w obrębie trzonu kości udowej występuje zwykle w następstwie urazu wysokoenergetycznego, to znaczy wymagającego dużej siły przyłożonej bezpośrednio lub pośrednio do kości udowej. Urazy wysokoenergetyczne wielokrotnie powodują istotne obrażenia nie tylko w samej okolicy złamania kości udowej, ale również są związane z urazami wielomiejscowymi lub wielonarządowymi.

Pod względem anatomicznym $\mathrm{u}$ dorosłych złamaniem trzonu kości udowej nazywamy złamanie znajdujące się w odcinku pomiędzy $5 \mathrm{~cm}$ dystalnie od krętarza mniejszego i $5 \mathrm{~cm}$ proksymalnie od guzka przywodzi- 
- Spiral fractures - typically occurring when the strength is applied spirally on the femur with the foot and the lower leg stabilized on the ground.

- Transverse and oblique fractures-most commonly occurring when the strength is applied directly on the femur or through excessive strength bending the femur.

- Comminuted and multilevel fractures - mostly occurring via the mechanism of direct trauma as a result of high-energy trauma accompanied by very serious multiorgan trauma.

- Pathological fractures may also occur. They are associated with the pathological weakening of the osseous tissue, which becomes more prone to injury. Therefore, those fractures result from low-energy trauma.

The clinical manifestations of femoral shaft fractures include edema and severe local pain. Fractures accompanied by the dislocation of bone fragments are associated with the disruption of the limb axis or even visible bone in case of open fractures. The position of bone fragments is determined by the activity of thigh muscles and the location of the fracture cleft (4).

Fractures are diagnosed on the basis of clinical examination and imaging tests. A radiograph executed in two views (anteroposterior and lateral) is the basic imaging test.

Notably, femoral shaft fractures may be associated with concomitant trauma. The top priority in case of multiorgan trauma is the treatment of injuries which are directly life-threatening, not only in terms of the locomotor system. It is possible to introduce routine procedures of the traumatology of the locomotor organs only after the stabilization of vital signs.

The rupture of large vessels and massive bleeding may be the most severe early complications of femoral shaft fractures. Femoral shaft fractures without an injury to large vessels may be associated with the extravasation of a considerable amount of blood. R. Lieurance demonstrated that the average extravasation of blood secondary to closed femoral shaft fracture was $1276 \mathrm{ml}$, with the lowest amount noted being 740 $\mathrm{ml}$, and the highest - as much as $2620 \mathrm{ml}$ (5). Femoral shaft fractures may lead to hypovolemic shock, which is a life-threatening condition, particularly in patients with other injuries. Such patients frequently require early surgical intervention and hospitalization in an Intensive Care Unit (6). Vascular injury concomitant with a fracture is an absolute indication for an urgent surgery performed by an orthopedist and a vascular surgeon. A procedure involving the stabilization of a fracture and restoration of circulation in the affected limb should be performed in any surgical department, because transporting a patient with such cieli (3). Złamania ze względu na przebieg szczeliny złamania wyróżnia się:

- Złamania spiralne - typowo występują, gdy siła działa skrętnie na kość udową, przy ustabilizowanej na podłożu stopie z podudziem.

- Złamania poprzeczne i skośne - najczęściej pojawiają się, gdy siła działa bezpośrednio na kość udową lub poprzez nadmierną siłę zginającą kość udową.

- Złamania wieloodłamowe i wielopoziomowe - powstają najczęściej w mechanizmie urazu bezpośredniego w następstwie urazów wysokoenergetycznych, towarzysząc bardzo poważnym urazom wielonarządowym.

- Wyróżnia się także złamania patologiczne, które występują w sytuacji osłabienia chorobowego tkanki kostnej, która jest bardziej podatna na uraz, w związku z czym do złamań dochodzi przy zdarzeniach niskoenergetycznych

Objawami klinicznymi złamania trzonu kości udowej są: obrzęk i silna bolesność miejscowa. W przypadku złamań z towarzyszącym przemieszczeniem odłamów kostnych obserwuje się zaburzenie osi kończyny, a nawet $\mathrm{z}$ uwidocznieniem kości w przypadku złamań otwartych. Ustawienie odłamów kostnych uwarunkowane jest działaniem mięśni uda i umiejscowieniem szczeliny złamania (4).

Złamanie rozpoznaje się na podstawie badania przedmiotowego oraz badań obrazowych. Podstawowym badaniem jest zdjęcie radiologiczne wykonane w dwóch projekcjach: przednio-tylnej i bocznej.

W przypadku wystąpienia złamania trzonu kości udowej należy mieć na uwadze potencjalne urazy współistniejące. W przypadku obrażeń wielonarządowych priorytetem jest leczenie obrażeń bezpośrednio zagrażających życiu, nie tylko ze strony układu ruchu człowieka, a dopiero po stabilizacji czynności życiowych możliwe jest wdrażanie rutynowych procedur z zakresu traumatologii narządów ruchu.

Najpoważniejszym wczesnym powikłaniem złamania kości udowej może być uszkodzenie dużych naczyń i masywne krwawienie. Złamaniu kości udowej bez uszkodzenia dużych naczyń może towarzyszyć wynaczynienie dużej objętości krwi. R. Lieurance wykazał, że średnie wynaczynienie krwi spowodowane zamkniętym złamaniem kości udowej wynosiło $1276 \mathrm{ml}$, przy czym najmniejsze jaką odnotował to $740 \mathrm{ml}$, natomiast największe aż $2620 \mathrm{ml}$ (5). Następstwem złamania trzonu kości udowej może być wstrząs hipowolemiczny, który jest stanem zagrożenia utraty życia, w szczególności u pacjentów z towarzyszącymi innymi obrażeniami. Chorzy z takimi urazami często wymagają wczesnej interwencji chirurgicznej i hospitalizacji w Oddziale Intensywnej Terapii (6). Uszkodzenie naczyń z towarzyszącym złamaniem jest bezwzględnym 
a diagnosis to a specialist facility may contribute to limb ischemia, necrosis and the necessity to amputate the limb. It may be a condition posing a direct threat to the patient's life (7).

The examination of a patient with a femoral shaft fracture should always include the assessment of an injury to the proximal an distal epiphysis of the femur. Fractures affecting the neck of the femur rarely coexist with femoral shaft fractures (1 to $8 \%$ of cases). However, over $30 \%$ are undiagnosed in this group. They are diagnosed later, usually as wedge or stress fractures. They may be diagnosed with anteroposterior and axial view radiographs aimed at the neck of the femur. Optionally, computed tomography (CT) may be performed. CT scans are characterized by high sensitivity and specificity. In approximately $40 \%$ of cases of femoral shaft fractures the patient experiences an injury within the knee joint, including damage to ligaments and menisci. Therefore, patients may need a magnetic resonance scan of the knee $(8,9)$.

Treatment modality depends on the patient's age, type of fracture and its location. The most common modality in the treatment of femoral shaft fractures in adults is X-ray-guided reposition and the intramedullary stabilization of the fracture with the use of a locking bolt (4). As regards children, the operative treatment of femoral shaft fractures has been in use more commonly for the past few decades. Beforehand, pediatric patients had usually been treated conservatively with the use of traction and/or a plaster cast. However, operative methods are used more and more frequently $(10,11)$. Indirect and direct traction is used in a lower percentage of children. Neonates, infants and children below 5 years of age may be treated conservatively with immobilization in a plaster cast. Children over 5 usually undergo intramedullary stabilization with titanium elastic nailing. Children older than 12-13 and young adults may undergo stabilization with intramedullary locking bolts (12). In case of open fractures treatment should be performed with an external fixator.

\section{THE AIM OF THE STUDY}

The study aimed at the presentation of the epidemiology of femoral shaft fractures in Poland with particular attention paid to the year-over-year trend and the division into age groups. An additional aim included the analysis of the causes of femoral shaft fractures in the pediatric population basing on the experiences of Pediatric Teaching Clinical Hospital, University Clinical Center of the Medical University of Warsaw. wskazaniem do pilnego leczenia operacyjnego z udziałem lekarza ortopedy i chirurga naczyniowego. Wykonanie zabiegu stabilizującego złamanie i przywracającego krążenie w kończynie powinno być dokonane w każdym oddziale chirurgicznym, gdyż przewożenie pacjenta $z$ takim rozpoznaniem do ośrodka specjalistycznego może spowodować niedokrwienie kończyny, martwicę, a nawet konieczność przeprowadzenia amputacji kończyny. Może to być stan bezpośredniego zagrożenia życia chorego (7).

Badając pacjenta ze złamaniem trzonu kości udowej zawsze trzeba brać pod uwagę obrażenia końca bliższego i końca dalszego kości udowej. Przykładowo, złamania szyjki kości udowej w niewielkim odsetku przypadków współwystępują wraz ze złamaniami trzonu kości udowej (od 1 do $8 \%$ przypadków), ale w tej grupie w ponad $30 \%$ przypadków są one nierozpoznawane. Najczęściej w późniejszym okresie rozpoznaje się wtedy złamania zaklinowane lub zmęczeniowe. Celem ich wykrycia należy wykonać zdjęcie RTG w projekcjach przednio-tylnej i osiowej celowane na szyjkę kości udowej lub zlecić badanie Tomografii Komputerowej. Badanie TK charakteryzuje się wysoką czułością i swoistością. W około $40 \%$ przypadków złamań trzonów kości udowej występują obrażenia w obrębie stawów kolanowych, w tym uszkodzenia więzadeł, łąkotek, dlatego pacjenci mogą wymagać wykonania badania rezonansu magnetycznego kolana $(8,9)$.

Metoda leczenia zależy od wieku chorego, typu złamania i jego lokalizacji. Najczęściej stosowaną metodą leczenia złamań trzonu kości udowej u osób dorosłych jest repozycja pod kontrolą monitora RTG i stabilizacja śródszpikowa złamania z użyciem gwoździa ryglowanego (4). W ostatnich dekadach lat u dzieci coraz częściej stosuje się metody leczenia operacyjnego złamań trzonów kości udowej. Wcześniej w grupie pacjentów pediatrycznych dominowały metody leczenia zachowawczego: leczenie na wyciągu i/lub w opatrunku gipsowym, jednakże coraz częściej stosuje się metody operacyjne $(10,11)$. Mniejszy odsetek dzieci leczony jest z użyciem wyciągów pośrednich i bezpośrednich. Noworodki, niemowlęta i dzieci poniżej 5 roku życia można leczyć zachowawczo unieruchomieniem w opatrunku gipsowym. Najczęściej stosowaną metodą u dzieci powyżej 5 roku życia jest stabilizacja śródszpikowa z użyciem elastycznych prętów tytanowych. U dzieci powyżej 12-13 roku życia i młodych dorosłych można zastosować gwóźdź śródszpikowy ryglowany (12). Złamania otwarte są wskazaniem do leczenia $\mathrm{z}$ użyciem stabilizatora zewnętrznego 


\section{MATERIAL AND METHODS}

The study included patients treated between 2015 and 2018. The data were obtained in June 2019 from the Department of Analysis and Strategy of the National Health Fund (DAS NHF). Data concerning detailed examinations of pediatric patients were obtained in 2017-2018 from Pediatric Teaching Clinical Hospital (PTCH), University Clinical Center (UCC) of the Medical University of Warsaw (MUW).

In both cases the data were retrieved from electronic records based on the International Statistical Classification of Diseases and Health Problems ICD-10, including all those records in which one of the diagnoses was described as S72.3, which means a patient with a femoral shaft fracture.

The data obtained from the Department of Analyses and Strategies of the National Health Fund were subjected to statistical analysis with Excel 2016.

Data retrieved from Pediatric Teaching Clinical Hospital, University Clinical Center of the Medical University of Warsaw only covered the period of 20172018, because before that time the hospital had not had a department of orthopedics and traumatology and had not admitted patients with such injuries. The data were subjected to qualitative analysis, during which medical records were used to determine the reason for the femoral shaft fracture and to classify the fractures into: high-energy, low-energy and pathological fractures.

\section{RESULTS}

In 2015-2018 the National Health Fund recorded 16996 unique cases of inpatients with femoral shaft fractures. A rising trend was noted in the number of femoral shaft fractures in the analyzed period, starting with 4046 cases in 2015, up to 4396 patients in 2018. The tendency is presented in Figure 1 along with the presentation of the number of patients annually.

Data obtained from DAS NHF were multiplied by demographic tables of the population of Poland published by the Statistics Poland, which led to the determination of the incidence of femoral shaft fractures in Poland. It was calculated that the incidence rate of femoral shaft fractures was 10.5/100 000 inhabitants annually in the years 2015-2018.

Due to the fact that professional literature indicated substantial differences between individual age groups as regards the occurrence of this pathology, we compared data from the Statistics Poland demographic tables with data concerning age and determined the incidence depending on individual age groups. The incidence of femoral shaft fractures

\section{CEL PRACY}

Celem pracy jest przedstawienie epidemiologii złamań trzonów kości udowej w Polsce, ze szczególnym uwzględnieniem tendencji rok do roku i z podziałem na grupy wiekowe. Celem dodatkowym pracy jest analiza przyczyn złamań trzonów kości udowej wśród pacjentów pediatrycznych, na podstawie doświadczeń Dziecięcego Szpitala Klinicznego Uniwersyteckiego Centrum Klinicznego Warszawskiego Uniwersytetu Medycznego.

\section{MATERIAŁ I METODY}

Materiał obejmuje chorych leczonych w latach 20152018. Dane zostały uzyskane w czerwcu 2019 roku z Departamentu Analiz i Strategii Narodowego Funduszu Zdrowia (DAiS NFZ). W przypadku szczegółowego badania pacjentów pediatrycznych dane dotyczą chorych z lat 2017-2018 i zostały uzyskane z Dziecięcego Szpitala Klinicznego (DSK) Uniwersyteckiego Centrum Klinicznego Warszawskiego Uniwersytetu Medycznego.

W obydwu przypadkach źródłem danych była elektroniczna dokumentacja oparta na Międzynarodowej Statystycznej Klasyfikacji Chorób i Problemów Zdrowotnych ICD-10, w której za pacjenta ze złamaniem trzonu kości udowej uznano te wszystkie rekordy, w których jednym z postawionych rozpoznań było $\mathrm{S} 72.3$, tj. złamanie trzonu kości udowej.

Dane uzyskane z Departamentu Analiz i Strategii Narodowego Funduszu Zdrowia poddano analizie i opracowano statystycznie w programie Excel 2016.

Dane uzyskane z Dziecięcego Szpitala Klinicznego Uniwersyteckiego Centrum Klinicznego Warszawskiego Uniwersytetu Medycznego obejmowały jedynie lata 2017-2018, gdyż w latach poprzednich szpital nie posiadał oddziału ortopedii i traumatologii i nie przyjmował pacjentów z tego typu urazami. Posiadane dane poddano analizie jakościowej, w trakcie której na podstawie dokumentacji medycznej ustalono przyczynę złamania trzonu kości udowej i zakwalifikowano do poszczególnych grup złamań: wysokoenergetyczne, niskoenergetyczne oraz patologiczne.

\section{WYNIKI}

Narodowy Fundusz Zdrowia w latach 2015-2018 odnotował 16996 unikatowych przypadków pacjentów hospitalizowanych ze złamaniami trzonów kości udowej. Odnotowano tendencje rosnące w liczbie złamań trzonów kości udowej w analizowanym okresie, zaczynając od 4046 przypadków w roku 2015, aż do 4396 pacjentów w roku 2018. Tendencję tą przedstawiono na Rycinie 1 (Fig.1), wraz z prezentacją liczby pacjentów rocznie. 


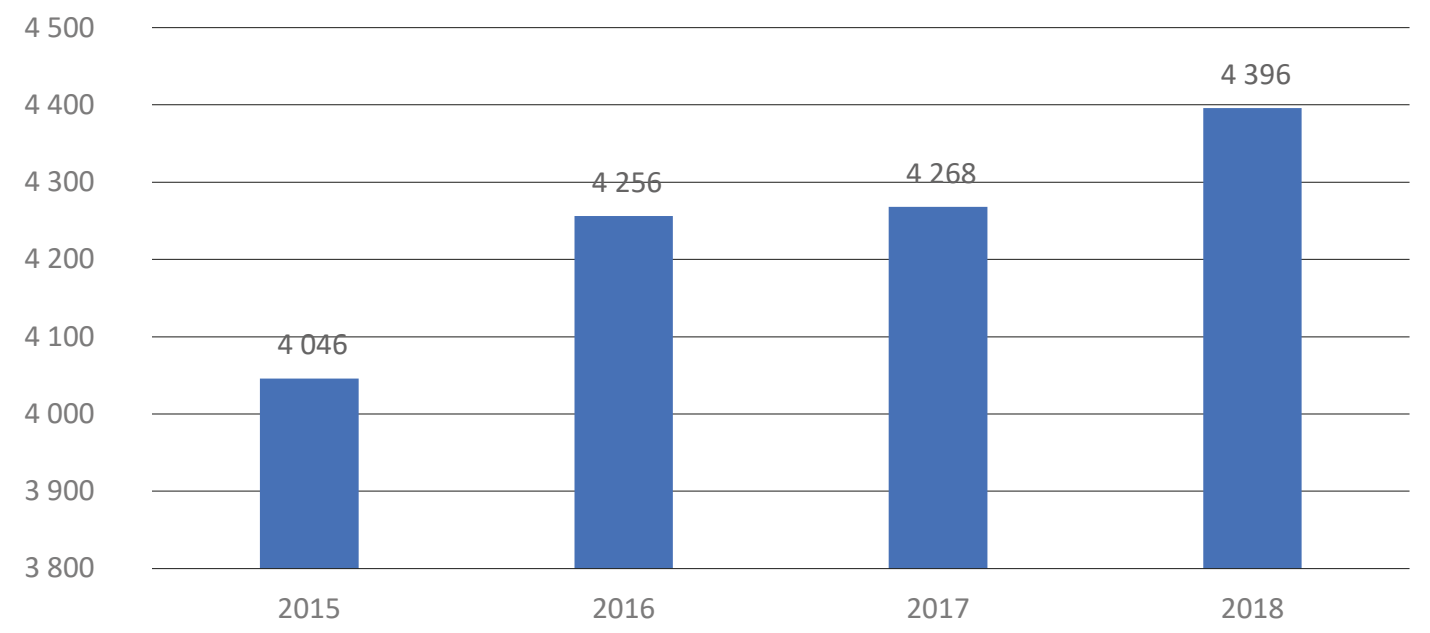

Fig. 1. The number of patients with femoral shaft fractures in Poland in 2015-2018.

Ryc. Liczba pacjentów ze złamaniami trzonów kości udowej w Polsce w latach 2015-2018

was higher (approx. 11.1./100 000 individuals/year) during the first 10 years of life. Subsequently, the incidence decreased until it reached 2.9/100 000 individuals/year in the age group between 40 and 49. Then, it started to increase significantly with the occurrence of surges until it reached 55.2/100 000 inhabitants/year in the group of individuals aged over 90 (Fig. 2).

We also decided to analyze the data with regard to deaths occurring in the group of patients hospitalized due to femoral shaft fractures. During the first year following the first hospitalization $16 \%$ of patients died due to a femoral shaft fracture, including 5\% of deaths during the first 7 days after the hospitalization started, $2 \%$ between days 8 and $30,6 \%$ between days 31 and 180 and another 3\% between days 181 and 365 (Fig. 3).
Dane DAiS NFZ przemnożono przez tabele demograficzne liczby ludności Polski udostępnione przez Główny Urząd Statystyczny, dzięki czemu uzyskano informację na temat zapadalności na złamania trzonu kości udowej w Polsce. Wyliczono, że w latach 20152018 współczynnik zapadalności na złamania trzonu kości udowej wynosił 10,5/100 000 mieszkańców / rok.

Ze względu na opisywane w literaturze znaczne różnice $\mathrm{w}$ poszczególnych grupach wiekowych w występowaniu tego typu złamania, nałożono dane $\mathrm{z}$ tabel demograficznych GUS na dane zależnie od wieku i ustalono zapadalność w zależności od przynależności do poszczególnych grup wiekowych. Częstość występowania złamań trzonów kości udowej w pierwszych 10 latach życia była większa (około 11,1 / 100000 osób / rok), po czym obserwuje się zmniejszanie częstości występowania, aż do 2,9 / 100000 osób / rok w przedziale 40-49 lat. Następnie częstość zaczyna istotnie wzrastać,

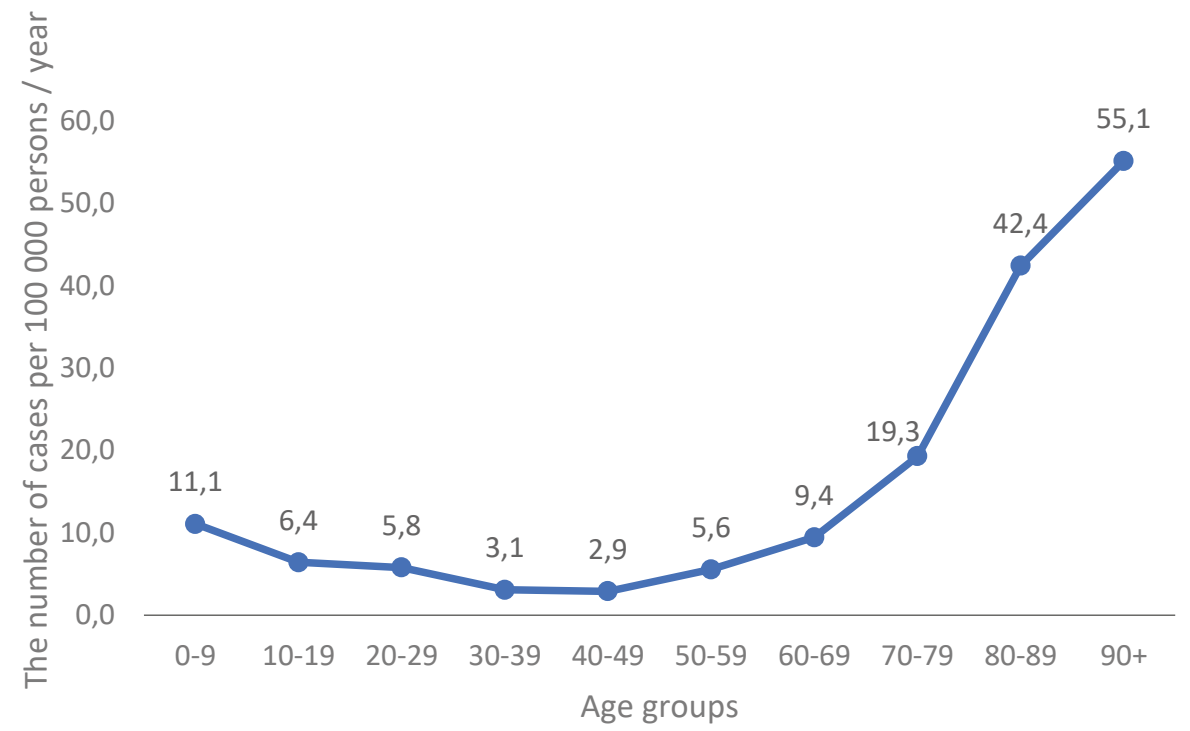

Fig. 2. Femoral shaft fractures depending on the age group in Poland in 2015-2018.

Ryc.2.Zapadalność na złamanie trzonu kości udowej w zależności od grupy wieku w Polsce w latach 2015-2018 


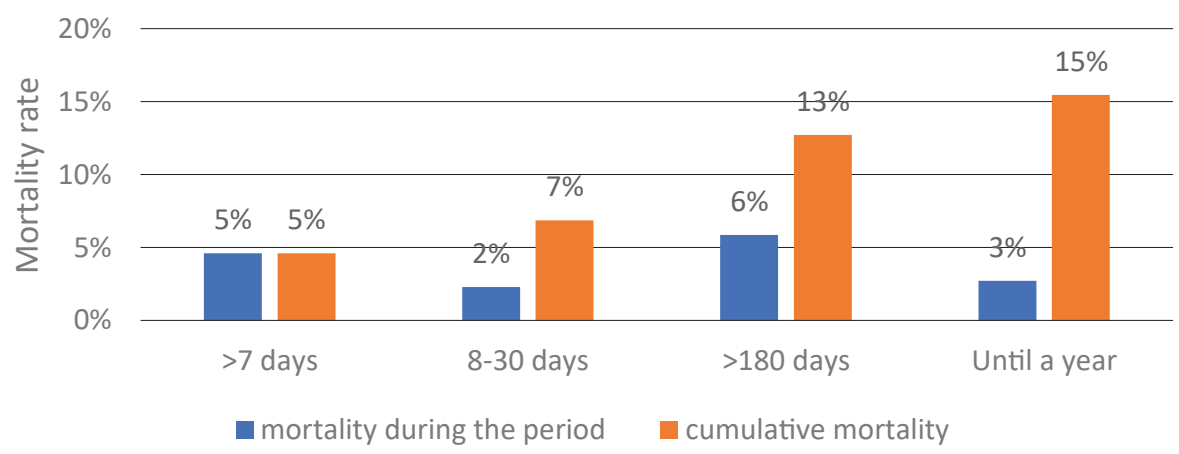

Fig. 3. Mortality in patients hospitalized with the diagnosis of a femoral shaft fracture.

Ryc.3.Śmiertelność pacjentów hospitalizowanych z diagnozą złamań trzonów kości udowej

As regards the patients of $\mathrm{PTCH}, 43$ patients were found to be diagnosed with S72.3 which was stated in the discharge report. A total of 39 individuals $(\mathrm{N}=39)$ were qualified for further analyses. The cause of the injury could not be specified in the remaining 4 cases, because the information was missing in the medical records. On admission to PTCH the youngest patient with a femoral shaft fracture was several days old, while the oldest was over 17 years old. The group included 20 boys and 19 girls at the average age of 7 years.

High-energy trauma was responsible for the fracture in 22 out of 39 patients, which constituted $56 \%$ of all cases. Low-energy trauma was the cause of the fracture in 12 cases (31\%), and pathological fractures - in 5 cases (13\%) (Fig. 4).

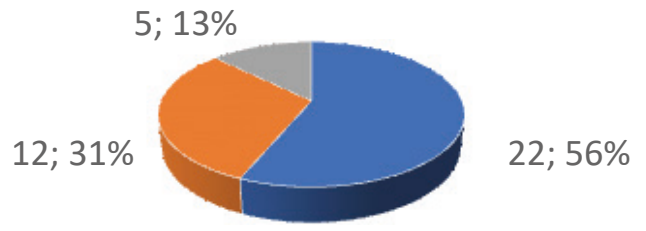

\section{high-energy fractures pathological fractures \\ - low-energy fractures}

Fig. 4. Types of femoral shaft fractures in the patients of PTCH UCC MUW.

Ryc.4. Grupy złamań trzonów kości udowej u pacjentów Dziecięcego Szpitala Klinicznego UCK WUM

As regards the group of high-energy trauma, injuries sustained while using a trampoline were the most common, followed by car accidents or accidents while using motor scooters or bicycles (Tab. I). The average age of a high-energy trauma patient was 8.5 years with $59 \%$ predominance of boys.

The dominant causes of low-energy trauma were: falls on the same level or from a minor height, e.g. a chair. The average age of a low-energy trauma patient was 5.5 years with no sex-related difference (50\% of boys, $50 \%$ of girls). by w grupie powyżej 70 roku życia odnotować skokowe wzrosty, aż do 55,1 / 100000 mieszkańców / rok w grupie osób powyżej 90 lat (Fig. 2).

Postanowiono przeanalizować także dane pod kątem występowania zgonu u pacjentów hospitalizowanych z powodu złamania trzonu kości udowej. W okresie roku od pierwszej hospitalizacji z powodu złamania trzonu kości udowej zmarło 16\% pacjentów, na co składały się zgony do 7 dni od rozpoczęcia hospitalizacji w liczbie $5 \%$, od 8 do 30 dnia $2 \%$, od 31 do 180 dnia $6 \%$ i od 181 do 365 dnia kolejne 3\% (Fig. 3).

Wśród pacjentów DSK w dokumentacji elektronicznej odnotowano 43 chorych z rozpoznaniem S72.3 umieszczonym na karcie wypisowej, spośród nich do dalszych prac zakwalifikowano 39 rekordów $(\mathrm{N}=39)$, gdyż w 4 przypadkach dokumentacja medyczna nie pozwalała na ustalenie przyczyny urazu. Najmłodszy chory w chwili przybycia do DSK ze złamaniem trzonu kości udowej miał kilkanaście dni, najstarszy ponad 17 lat. Średnia wieku wynosiła 7 lat, a rozkład płci wynosił 20 chłopców i 19 dziewcząt.

Wśród 39 pacjentów, aż u 22 za przyczynę urazu uznano wypadek wysokoenergetyczny, co stanowiło $56 \%$ wszystkich przypadków. W 12 przypadkach przyczyną był uraz niskoenergetyczny (31\%), a w 5 były to złamania o charakterze patologicznym (13\%) (Fig. 4).

Wśród urazów wysokoenergetycznych najczęstszą przyczyną były urazy doznane na trampolinie, a kolejną przyczyną wypadki komunikacyjne z udziałem pojazdów osobowych, skuterów lub rowerów (Tab. I). Przeciętny wiek chorego z urazem wysokoenergetycznym to 8,5 roku życia, z 59\% przewagą chłopców.

Wśród urazów niskoenergetycznych dominowały upadki z wysokości własnej lub z niewielkiej wysokości, na przykład z krzesła. Przeciętny wiek pacjenta $z$ niskoenergetycznym złamaniem kości udowej to 5,5 roku, bez różnicy wobec płci (50\% przypadków chłopcy, $50 \%$ dziewczęta).

W przypadku złamań patologicznych z 5 przypadków, aż w czterech za przyczynę złamań uznano wrodzoną łamliwość kości, łac. osteogenesis imperfecta. 
Table I. The most common causes of high-energy trauma in the pediatric population.

Tabela I. Najczęstsze przyczyny urazów wysokoenergetycznych w populacji pediatrycznej

\begin{tabular}{|l|l|}
\hline \multicolumn{2}{|c|}{ The most common causes of high-energy trauma in order of frequency } \\
\hline 1 & Injuries while using a trampoline \\
\hline 2 & Traffic accidents (cars, motor scooters, bicycles) \\
\hline 3 & Falls on the stairs of swimming pools \\
\hline 4 & Other sports-related injuries \\
\hline
\end{tabular}

Osteogenesis imperfecta (OI) was responsible for 4 out of 5 cases of pathological fractures.

\section{DISCUSSION}

Polish professional literature concerning femoral fractures includes scarce data about their epidemiology. The issue of epidemiology was entirely disregarded or described to a limited extent in the majority of articles and chapters. According to one study the femur is most commonly broken via an indirect mechanism as a result of high-energy trauma in $70 \%$. It was observed in physically active individuals aged $18-65$ in 40\% (13). W. Rusek et al. calculated that in case of pediatric patients femoral shaft fractures constituted approx. $10 \%$ of all fractures in children hospitalized in the Department of Pediatric Orthopedics and Traumatology in Rzeszów. However, the paper lacked a reference to the population size or the estimation of the incidence of this phenomenon (14). More detailed data may be found in international professional literature. However, the data refer to international populations. $K$. Egol et al. reported that the total incidence of femoral shaft fractures was about 10/100 000 persons annually. At the same time, they indicated a high correlation with the sex and age, with the peak of fractures in men occurring at the age of 15-24, while in women - over 75 years. Young men experience fractures as a consequence of high-energy trauma, while elderly women - as a result of low-energy falls (15). Rune Hedlund in 1986 demonstrated a similar incidence of the fractures in the inhabitants of Stockholm. Furthermore, the highest incidence of femoral shaft fractures was observed in the course of a severe injury in men aged 20-29. In case of women the risk of femoral shaft fractures increased by $10 \%$ annually with every year over 65 years of age. On average, the incidence of fractures was about $1 / 10$ 000 inhabitants per year (16). A more recent study conducted in northern Europe (Finland) with a 10-year follow-up period revealed the incidence of fractures at 9.9/100 000 inhabitants annually. The authors reported $75 \%$ of high energy fractures and $25 \%$ low energy fractures. The dependence on sex and age was the same (the fractures occurred several times more commonly in young men and elderly women) (17).

\section{DYSKUSJA}

W piśmiennictwie polskim dotyczącym złamań kości udowej jest niewiele doniesień dotyczących epidemiologii tych złamań. W większości artykułów i rozdziałów tematyka epidemiologii jest zupełnie pominięta lub występuje w niewielkim zakresie, przykładowo autor jednej z publikacji podaje: „Kość udowa najczęściej ulega złamaniu z mechanizmu pośredniego w następstwie urazów wysokoenergetycznych u 70\%. Dotyczy osób aktywnych fizycznie w wieku 18-65 lat u 40\%." (13). W przypadku pacjentów pediatrycznych $W$. Rusek z zespołem obliczyli, że około $10 \%$ wszystkich złamań hospitalizowanych w oddziale ortopedii i traumatologii dziecięcej w Rzeszowie to były złamania trzonów kości udowych, brak jednak odniesienia do wielkości populacyjnej, czy też szacowania częstości występowania zjawiska (14). Jedynie w literaturze zagranicznej można znaleźć dokładniejsze dane, ale odpowiadające tamtejszym populacjom. K. Egol i wsp. podają, że całkowita częstość złamań trzonów kości udowej wynosiła około 10/ 100000 osób / rok. Jednocześnie wskazują, że istnieje duża zależność od płci i wieku, gdzie szczyt złamań to dla mężczyzn wiek 15-24 lata, a dla kobiet jest to wiek powyżej 75 r.ż. U młodych mężczyzn złamania powstają $\mathrm{w}$ następstwie urazów wysokoenergetycznych, a u starszych kobiet w mechanizmie upadków niskoenergetycznych (15). Rune Hedlund w 1986 roku wykazała podobną częstość złamań w populacji sztokholmskiej, w szczególności, że najwyższą częstość złamań trzonu kości udowej w przebiegu ciężkiego urazu mają mężczyźni w wieku 20-29 lat. W przypadku kobiet ryzyko złamania trzonu kości udowej wzrasta o $10 \%$ rocznie z każdym rokiem powyżej 65 roku życia. Przeciętnie częstość występowania złamań wynosi w okolicach 1/10 000 mieszkańców / rok (16). Kolejne, nowsze badanie północno-europejskie, tym razem z Finlandii, z dziesięcioletnim okresem obserwacji, wykazało częstość złamań na 9,9/100 000 mieszkańców rocznie. Odnotowano tam $75 \%$ złamań wysokoenergetycznych i $25 \%$ złamań niskoenergetycznych, a zależność od płci i wieku była taka sama (złamania kilkukrotnie częściej występowały u młodych mężczyzn oraz starszych kobiet) (17). Szwedzkie badanie $z$ lat 1998-2004 wskazało na całkowitą liczbę przypadków 10,3/100 000 mieszkańców / rok, jednakże z bardzo dużą różnicą dotyczącą przedziałów wiekowych. W pierwszych 10 latach 
A Swedish study conducted in the years 1998-2004 indicated the total number of cases at 10.3/100 000 inhabitants annually with a considerable difference regarding age groups. The incidence was 12.1 (boys 16.9, girls 7.1) over the first 10 years of life regardless of the sex. Afterwards, it gradually decreased until it reached 3.0 in persons aged 30-39. Then, the risk of femoral shaft fracture increased until the level of $110 / 100000$ per year in the group aged $90+$ (women 132.3, men - only 45.6) (18). A study from Semey in Kazakhstan with a 3-year follow-up revealed the incidence of femoral shaft fractures at 9.7 cases per 100000 inhabitants annually (19).

The present authors determined the total incidence rate of femoral shaft fractures at 10.5/100 000 inhabitants per year, which is consistent with data obtained from international literature. The incidence of femoral shaft fractures is similar in Poland and internationally. No significant differences are noted between populations. One striking feature of the results is the significant influence of age diversity on the incidence of the fractures. The incidence curve is high in children below 10 and then it decreases to reach the minimum in people aged 30 to 49. Subsequently, it starts to increase significantly to reach the peak in the oldest population in which the incidence of femoral shaft fractures was estimated at over 55 cases per 100000 inhabitants annually. Notably, the limitation of the assumed source of data from the National Health Fund is related to its dependence on the quality of work of people who supply data concerning diagnoses to the electronic systems. The quality of the obtained data may also be affected by cases of omitting S72.3 code in diagnoses or recording them with other codes, e.g. S72.7 (numerous fractures of the femur) or T02.5 (fractures within numerous areas of both lower extremities). Moreover, the quality of the data may be affected by other situations, when, due to an error, S72.3 code was recorded instead of another, correct code. Such a situation might occur particularly at facilities, where an administrative worker, and not medical personnel, was responsible for completing ICD-10 codes.

During statistical analysis a high percentage of deaths was noted in patients who sustained a femoral shaft fracture. We concluded that even $16 \%$ of patients may die over the first year after the event. Regarding the above, it is worth noting that the data are purely statistical, obtained from the Department of Analyses and Strategies of the National Health Fund, without information concerning the age of patients, the main cause of death, concomitant diseases and concomitant diagnoses. Further research is necessary to investigate the effect of femoral shaft fractures on mortality comprising information about życia częstość liczona niezależnie od płci wynosiła 12,1 (chłopcy 16,9, dziewczynki 7,1), po czym sukcesywnie spadała, aż do poziomu 3,0 w przedziale wiekowym 30-39. Następnie pojawia się wzrost ryzyka złamania trzonu kości udowej aż do poziomu 110 / 100000 / rok w grupie wiekowej 90+ (kobiety 132,3, a mężczyźni jedynie 45,6) (18). Badanie z trzyletnim okresem obserwacji z Semej w Kazachstanie oszacowało częstość występowania złamań trzonu kości udowej na 9,7 przypadków na 100000 mieszkańców rocznie (19).

W niniejszej pracy określono ogólny współczynnik zapadalności na złamania trzonu kości udowej wynosił 10,5/100 000 mieszkańców / rok, co jest zbieżne z danymi uzyskiwanymi z literatury zagranicznej. Częstość występowania złamań trzonów kości udowej w Polsce jest zbliżona do danych światowych i wskazuje na brak istotnych różnic pomiędzy populacjami. Zwraca uwagę istotny wpływ zróżnicowania wiekowego na częstość występowania złamań. Krzywa zapadalności jest wysoka wśród dzieci do 10 roku życia, po czym spada osiągając minimum w przedziale od 30 do 49 roku życia. Następnie zaczyna istotnie wzrastać osiągając apogeum w najstarszych grupach wiekowych, gdzie oszacowano częstość występowania złamań trzonu kości udowej na ponad 55 przypadków na 100000 mieszkańców na rok. Jednocześnie należy pamiętać, że ograniczeniem przyjętego źródła danych z Narodowego Funduszu Zdrowia jest jego zależność od jakości pracy osób wprowadzających rozpoznania do systemów elektronicznych. Na jakość uzyskanych danych mogły mieć wpływ przypadki pominięcia w podawanych rozpoznaniach kodu S72.3 lub ujęcie go w innych kodach, na przykład S72.7 „liczne złamania kości udowej” czy też T02.5 „złamania obejmujace liczne okolice obu kończyn dolnych". Również wpływ na jakość uzyskanych danych mogą mieć sytuacje przeciwne, gdy w wyniku omyłki wprowadzono błędnie kod S72.3 zamiast innego, właściwego. Taka sytuacja mogła mieć miejsce w szczególności w miejscach, gdzie za wprowadzanie kodów ICD-10 odpowiedzialny jest pracownik administracyjny, a nie personel medyczny.

W trakcie prac statystycznych zwrócono uwagę na występowanie wysokiego odsetka zgonów u pacjentów, którzy doznali złamania trzonów kości udowej. Wnioskujemy, że aż 16\% chorych może ponieść zgon w ciągu jednego roku od zdarzenia. Biorąc pod uwagę takie informacje, należy również mieć na uwadze, że są to dane czysto statystyczne uzyskane z Departamentu Analiz i Strategii Narodowego Funduszu Zdrowia, bez danych na temat wieku chorych, głównej przyczyny zgonu, chorób współistniejących i towarzyszących rozpoznań wspólistniejących. Kwestia zbadania wpływu złamania trzonu kości udowej na śmiertelność z uwzględnieniem mechanizmu zdarzenia, towarzyszących obrażeń i ob- 
the mechanism of the event, associated injuries and the medical history of the patients.

As regards the pediatric population we observed a considerable percentage of pathological and low energy femoral shaft fractures, which constituted as much as $44 \%$ of cases. Other authors observed a significantly more marked incidence of high-energy trauma $(17,20)$.

Unlike the authors of other studies, we noted no significant differences in the incidence of femoral shaft fractures depending on the sex in individual age groups. Other authors reported a higher incidence of the fractures in boys compared to girls both in Poland (14) and worldwide $(17,20,21)$.

\section{CONCLUSIONS}

The epidemiology of femoral shaft fractures in Poland in the second decade of the 21st century is similar to cases described in international literature for the past 40 years. The incidence of femoral shaft fractures is comparable in Poland, Sweden, Finland, Kazakhstan and the USA. The Polish population is characterized by tendencies similar to those described in international studies suggesting the increased risk of femoral shaft fractures in adolescence and a very significant increase in the risk in the elderly.

The experience of Pediatric Teaching Clinical Hospital, University Clinical Center of the Medical University of Warsaw showed that, currently, trampoline jumping is the main reason for highenergy fractures of the femoral shaft in children, with traffic accidents being the second one.

\section{REFERENCES}

1. Court-Brown C, Caesar B. Epidemiology of adult fractures: A review. Injury 2006; 37 (8):691-697. doi: 10.1016/j.injury.2006.04.130.

2. Ciszek B, Krasucki K, Aleksandrowicz R. Mała anatomia kliniczna. Wyd 1. Warszawa: Wydaw. Lek. PZWL; 2019:40.

3. Smith WR, Stahel PF, Suzuki T, et al. Musculoskeletal Trauma Surgery. W: Skinner HB, McMahon PJ. Current Diagnosis \& Treatment. Orthopedics. Wyd 5. USA: McGraw-Hill Medical 2013:59-62.

4. Gągała J, Michnowski P, Synder M, et al. Biodro i udo. W: Nowakowski A, Mazurek T. Ortopedia i traumatologia. Podręcznik dla studentów medycyny. Wyd 1. Poznań: Wydawnictwo Edukacyjne Exemplum; 2017:621-623.

5. Lieurance R, Benjamin JB, Rappaport WD. Blood loss and transfusion in patients with isolated femur fractures. J. Orthop. Trauma 1992. 6(2):175-179 doi: 10.1097/00005131-199206000-00007. ciążeń chorobowych pacjenta musi zostać poddana dalszym badaniom.

W przypadku populacji pediatrycznej zaobserwowano znaczący odsetek złamań trzonów kości udowych o charakterze patologicznym i niskoenergetycznym, stanowiły one aż $44 \%$ przypadków. Autorzy innych doniesień odnotowywują istotnie większą częstość występowania urazów wysokoenergetycznych $(17,20)$.

$\mathrm{W}$ przeciwieństwie do autorów innych publikacji nie odnotowaliśmy w poszczególnych grupach wiekowych istotnych różnic występowania złamań kości udowej w zależności od płci pacjenta. Autorzy innych doniesień odnotowywali większą częstość występowania złamań w grupie chłopców względem dziewcząt zarówno w Polsce (14) jak i na świecie (17, 20, 21).

\section{WNIOSKI}

Epidemiologia złamań trzonów kości udowej w Polsce $\mathrm{w}$ drugiej dekadzie XXI wieku nie różni się od przypadków opisywanych w literaturze zagranicznej w okresie ostatnich 40 lat. Zapadalność na złamania trzonu kości udowej jest tak samo częsta w Polsce, jak w USA, Szwecji, Finlandii i Kazachstanie. W populacji polskiej obserwuje się podobne tendencje jak w badaniach światowych, sugerujące zwiększone ryzyko występowania złamań trzonów kości udowej w wieku młodzieńczym oraz bardzo istotnie wzrastające ryzyko wraz z osiągnięciem wieku senioralnego.

Z doświadczeń Dziecięcego Szpitala Klinicznego Uniwersyteckiego Centrum Klinicznego Warszawskiego Uniwersytetu Medycznego wynika, że w chwili obecnej to skoki na trampolinie są główną przyczyną złamań wysokoenergetycznych trzonów kości udowych u dzieci, degradując na drugą pozycję wypadki komunikacyjne.

6. Babiak I, Górski R. Złamania kości udowej. W: Babiak I, Małdyk P. Traumatologia narządu ruchu. Skrypt dla studentów i lekarzy. Wyd 1. Warszawa: Wydawnictwo Warszawskiego Uniwersytetu Medycznego; 2016:77-80.

7. Kalewski A, Pieliński M, Dziak A. Uszkodzenia uda. W: Tylman D, Dziak A. Traumatologia narządu ruchu. Wyd 2. Warszawa: Wydaw. Lek. PZWL; 2012 (2):410-531.

8. Ricci W. Złamania trzonu kości udowej. W: Sanders R. Traumatologia układu ruchu. Wyd 1. Wrocław: Edra Urban \& Partner; 2009:295-314.

9. Słowiński W, Ruciński M, Słowiński K. Współistnienie złamań trzonu kości udowej i obrażeń stawu kolanowego - przypadek czy zależność? Nowiny Lekarskie 2006; 75 (1):3-6.

10. Heinrich S. The operative stabilization of pediatric diaphyseal femur fractures with flexible 
intramedullary nails. Operative Techniques in Orthopaedics 1995; 5(2):115-125 doi: 10.1016/ S1048-6666(95)80003-4.

11. Metaizeau JP. Use of flexible nails in children. Orthopaedic Proceedings 2002; 84-B:SUPP II:114-114.

12. Kusz D, Wojciechowski P. Obrażenia występujące u dzieci. W: Kusz D. Kompendium traumatologii. Wyd 1. Warszawa: Wydaw. Lek. PZWL; 2010:181197.

13. Ratyński G. Złamania trzonu kości udowej W: Marczyński WJ. Traumatologia narządu ruchu. Biologia i biomechanika leczenia. Wyd 1. Warszawa: Wydaw. Lek. PZWL; 2017:739-751.

14. Rusek W, Pop T, Jarochowicz S, et al. Najczęstsze urazy kończyn górnych i dolnych $u$ dzieci i młodzieży. Prz Med Uniw Rzesz Inst Leków 2010; 4:427-434.

15. Egol KA, Koval KJ, Zuckerman JD. Kompendium leczenia złamań. Wyd 1. Warszawa: Wydawnictwo Medyczne Medipage; 2012 (2):512-527.

16. Hedlund R, Lindgren U. Epidemiology of diaphyseal femoral fracture. Acta Orthopaedica Scandinavica 1986; 57(5):423-427, doi: 10.3109/17453678609014762.

17. Salminen S, Pihlajamäki $\mathrm{H}$, Avikainen V, et al. Population based epidemiologic and morphologic study of femoral shaft fractures. Clin Orthop Relat Res 2000; 372:241-249. doi: 10.1097/00003086200003000-00026.

18. Weiss RJ, Montgomery SM, Al Dabbagh Z et al. National data of 6409 Swedish inpatients with femoral shaft fractures: Stable incidence between 1998 and 2004. Injury 2009; 40(3):304 - 308. doi: 10.1016/j.injury.2008.07.017.

19. Myssayev A, Meirmanov S, Zhanaspayev M, et al. Femoral Shaft Fracture in Adult Victims in Semey, Kazakhstan from 2009-2011: An Epidemiological Retrospective Study. Life Sci J 2014;11(3):191-195.

20. Petković L, Djan I, Gajdobranski D, et al. Pediatric femur fractures, epidemiology and treatment. Vojnosanitetski pregled 2011; 68 (1):9-14. doi:10.2298/VSP1101009P.

21. Cooper C, Dennison EM, Leufkens HGM, et al. Epidemiology of Childhood Fractures in Britain: A Study Using the General Practice Research Database. J Bone Miner Res 2004;19:1976 -1981. doi: 10.1359/JBMR.040902.

Received: 24.04.2020

Otrzymano:24.04.2020 r.

Accepted for publication:30.09.2020

Zaakceptowano do publikacji: $30.09 .2020 \mathrm{r}$.

\section{Address for correspondence:} Adres do korespondencji:

Jan Stachurski

Zakład Medycyny Ratunkowej Dzieci, Warszawski Uniwersytet Medyczny, ul. Żwirki i Wigury 63a, 02-091 Warszawa tel.: +48 223179301 e-mail: jan.stachurski@wum.edu.pl 